\title{
(NE)SIGURNOST U ZATVORU
}

\author{
Goran JOVANIĆ \\ Univerzitet u Beogradu \\ Fakultet za specijalnu edukaciju i rehabilitaciju
}

Opšti cilj istraživanja je bio da se utvrdi stepen prisustva deprivacije sigurnosti kod osudenih lica u različitim tipovima kazneno-popravnih ustanova i povezanost deprivacije sa demografskim, socijalno-psihološkim, kriminološkim i penološkim karakteristikama. Istraživanje je imalo za cilj i sticanje naučnih saznanja o kvalitetu i intenzitetu deprivacije sigurnosti kao jedne od posledica izvršenja kazne zatvora i razlikama u doživljaju od strane različitih kategorija osudenih lica. Uzorak su činila 183 osuđena lica, muškog pola, na izvršsenju kazne zatvora u Kaznenopopravnom zavodu (KPZ) za maloletna i mlađa punoletna lica u Valjevu, KPZ Padinska Skela, u KPZ Požarevac i Okružnom zatvoru Pančevo. Ispitanici su anketirani opštim upitnikom kojim su prikupljeni podaci o varijablama vezanim za osnovne kriminološko-penološke i socijalno-psihološke podatke i Skalom za ispitivanje deprivacije sigurnosti-SIG (Radovanović, 1992) koja ima 34 pitanja po principu Likertove skale (Cronbach's $\alpha=0,952)$. Rezultati istraživanja ukazuju da oko $15 \%$ ispitanika iskazuje nisku depriviranost, oko 56\% povišenu i oko 28\% visoku depriviranost. Deprivacija sigurnosti ostvaruje statistički značajan odnos sa starošću $(r=0,163 ; p=0,028)$, tako što se porastom godina života povećava $i$ stepen depriviranosti. Sa drugim ispitivanim nezavisnim varijablama nije u korelaciji. Ova situacija nameće pitanja poštovanja pravila o kategorizaciji zatvora i raspoređivanju osudenih, posebne zaštite starih u zatvoru, separaciji agresivnih i opasnih osuđenika, nadzora nad njihovim ponašanjem, kontrole neformalnog osuđeničkog kolektiva i sličnih problema koji prate izvršenje kazne zatvora.

Ključne reči: kazna, zatvor, osuđeni, sigurnost, depriviranost

1 E-mail: goxi67@gmail.com 


\section{UVOD}

Primarna fokusiranost razvijenijih zemalja pomera se sa procesa kažnjavanja na korektivni tretman za vreme boravka u zatvoru (Green et al., 1992), osposobljavanje i pripremu za otpust i na prihvat po izlasku iz zatvora (Graffam, Shinkfield, 2009); ili na posledice neuspešne reintegracije u vidu recidivizma (Palermo, 2009). Proračun ulaganja u sadržajniji zatvorski tretman, obogaćen različitim programima pomoći i prevazilaženja uslova koji su kanalisali ponašanje osuđenog ka društveno neprihvatiljivom, ima za cilj smanjenje štete koja bi nastala ponovnim uključivanjem u nedozvoljene aktivnosti nakon zatvorske kazne (McDougall et al., 2003). Intenzivno osećanje ugroženosti i straha za ličnu bezbednost osuđenih umanjuje šanse za uspeh korektivnog penalnog tretmana.

Često se zaboravlja da se i u zatvoru radi o čoveku koji će po isteku zatvorske kazne (sem u izuzetnim slučajevima) ponovo zauzeti svoje mesto u svetu slobodnih ljudi. U isto vreme, od tog čoveka se očekuje da za vreme izvršenja zatvorske kazne trpi uslove ograničavanja i lišavanja kao kaznu za ono što je učinio protiv društva (Jovanić, 2011b). Paralelno sa tim očekivanjem prisutan je i zahtev da taj čovek u zatvorskim uslovima promeni svoje ponašanje u pravcu uzdržavanja od kriminalnih akata. Očekuje se od njega da se automatski po izlasku iz penalne ustanove odmah preobrati u slobodnog građanina, korisnog po sebe i društvo. Istovremeno se ne ulaže potrebna postpenalna podrška koja bi mu omogućila uspešnu reintegraciju u svet slobode i dovela ga do ostvarenja postavljenih zahteva.

Na jednoj strani stoje zahtevi za kaznom i odmazdom, na drugoj zahtevi za pozitivnim promenama, a na trećoj strani su osuđeni. Od njih se očekuje da u uslovima izolacije i prinude, često i straha za opstanak, nemaju otpore prema nastojanjima društva da ih istovremeno kazni i promeni u osobe koje više neće biti u sukobu sa zakonom. Takve stavove ističu i drugi autori koji upozoravaju na problem uticaja deprivacija na kasniji reintegrativni proces (Bucklen, Zajac, 2009). Dostupna su istraživanja koja se bave problemima i uslovima boravka osuđenih u ustanovama za izvršenje kazne zatvora (Lowenkamp, Latessa \& Smith, 2006) i refleksijom na kasniju pojavu recidivizma (Visher \& Travis, 2003), kako se ti uslovi reflektuju na nastanak deprivacija i koje posledice po njih to sve ostavlja. 
Recidivizam predstavlja poseban problem penalne prakse. Doživljava se delimično i kao neuspeh preduzetih mera penalne rehabilitacije (Jovanić, 2010a). Boravak osuđenog u zatvoru neminovno podrazumeva povinovanje velikom broju pravila i propisa uz neizbežan saživot sa drugim osuđenima.

Radovanović (1992) ukazuje da je osuđeni prinuđen da na malom prostoru živi u neprekidnom prisustvu ostalih osuđenika, od kojih mnogi imaju dugu karijeru fizičkih nasrtaja. Ne može se izbeći društvo ubica, lopova, prevaranata, seksualnih napasnika i agresivaca. Navodi Radovanovića (1992) ukazuju na postojanje straha i nesigurnosti od siledžija, izazova na odmeravanje snaga i straha da se osuđeni ne stigmatizuje kao kukavica, a ovi strahovi su direktna posledica konstantne izloženosti provokacijama, podlostima i lukavstvima u zatvorskoj životnoj situaciji.

Zajednički život osuđenih u takvoj atmosferi ima za posledicu osećanje nesigurnosti. Osuđeni strahuju od mogućnosti napada na svoj život, telesni integritet, ugled ili dostojanstvo. Stanje napetosti praćeno je očekivanjem i strepnjom da će, pre ili kasnije, osuđeni biti doveden u situaciju da brani sebe, svoju ličnost ili svoju skromnu imovinu (Jovanić, 2007).

Rezultati istraživanja (Jovanić, 2007; Radovanović, 1992; Sykes, 1958; Špadijer-Džinić, 1973) govore da je ovo osećanje prisutno kod većine zatvorenika. Kada osuđeni i ne smatra sebe za osobu koja će napasti ili eksploatisati drugog osuđenog, ipak veruje da su drugi osuđeni u mogućnosti da mu naude. Snažna fizička konstitucija nije garancija da osuđeni neće strahovati za svoju sigurnost. Najsnažniji i najagresivniji takođe strepe da mogu biti izazvani i ugroženi od strane pojedinaca ili grupe zatvorenika. Osećanje nesigurnosti doživljava se usled straha da će ga neko drugi staviti na „probu”, iskušavajući njegovu spremnost da brani svoju ličnost, prava ili imovinu. Poraz u toj borbi doveo bi do etiketiranja kao slabića i kukavice. Špadijer-Džinić (1973) zaključuje da gubitak sigurnosti dovodi do anksioznosti, kako usled mogućeg napada od strane drugog osuđenog, tako i usled neizvesnosti ishoda tog napada i dovođenja u pitanje sposobnosti osuđenog za odbranu. Odbrambena sposobnost osuđenog postaje tako predmet rasprave drugih osuđenih, što utiče na formiranje predstave koju je on imao o sebi u zatvoreničkom društvu. 
Ovu vrstu problema uviđa i Santos (1995) istražujući zatvorsku atmosferu u maksimalno obezbeđenom zatvoru. Uočava da osuđeni, koji po pravilu dolaze na izvršenje kazne zatvora na duži niz godina (pa i na doživotno) i susreću se sa sebi sličnima ili gorima od sebe, strahuju za sopstvenu sigurnost. Santos kaže da je atmosfera u zatvoru daleko od opuštajuće. Konstantna potreba za održavanjem slike o sebi kao nepobedivom, spremnom da odgovori na napad drugih osuđenih, podiže tenziju i doprinosi javljanju deprivacije sigurnosti.

Deo problema u vezi sa nastankom ove deprivacije nastaje i stoga što formalni sistem nije u mogućnosti da osuđenom licu pruži sigurnost $\mathrm{u}$ takvim situacijama. Apsolutni nadzor i potpuna kontrola nad osuđenima kose se i sa pravima na privatnost. Nije dozvoljeno elektronskim uređajima nadzirati svaki prostor koji osuđeni koriste. Osuđeni to i ne žele. Izbegavaju zaštitu od nesigurnosti reakcijom formalnog sistema, da ne bi bili okarakterisani od strane drugih zatvorenika kao cinkaroši ili ulizice. Otud izreka, proistekla iz Sajksovog istraživanja u Državnom zatvoru Nju Džerzija koja govori kako je najgora stvar u vezi sa zatvorom to što morate da živite sa drugim zatvorenicima (Sykes, 1958).

Privid osuđeničke solidarnosti u suprotnosti je sa prisutnim osećanjem nesigurnosti koje vlada u takvoj životnoj situaciji. Istraživanja deprivacije sigurnosti omogućavaju precizniji uvid u razlike u kvalitetu i intetnzitetu tih posledica u zavisnosti od ustanove u kojoj se izvršava kazna zatvora i faktora vezanih za lične karakteristike osuđenih. Sajks je ukazivao na čitav niz negativnih posledica, smatrajući ih univerzalnim i podjednako prisutnim kod svakog osuđenog lica i u svakom tipu kaznene ustanove (Sykes, 1958). Nešto drugačiji, diferencirani pristup ovom problemu imaju autori Špadijer-Džinić (1973) i Radovanović (1992). Oni tvrde da prisustvo i intenzitet negativnih posledica boravka u zatvoru zavise od ličnosti, zatvorskog iskustva pojedinca i drugih objektivnih uslova, posebno onih vezanih za tip penalne ustanove, odnosno za režim izvršenja kazne zatvora. Navedeni faktori deluju povezano i odražavaju se na osećanje nesigurnosti kod osuđenog. 


\section{CILJ ISTRAŽIVANJA}

Opšti cilj istraživanja je bio utvrđivanje prisustva i intenziteta deprivacije sigurnosti u različitim tipovima penalnih ustanova. Iz ovog opšteg cilja operacionalizovano je više parcijalnih ciljeva i to su: utvrđivanje korelativnih veza između: nivoa depriviranosti i tipa penalne ustanove; nivoa depriviranosti i demografskih karakteristika osuđenih; nivoa depriviranosti i socijalno-psiholoških karakteristika osuđenih i između nivoa depriviranosti i kriminološko-penoloških karakteristika osuđenih lica.

\section{METOD RADA}

Istraživanje deprivacije sigurnosti, za razliku od prethodno navođenih autora (Radovanović, 1992; Sykes, 1958; Špadijer-Džinić, 1973), koji su svoje analize bazirali na ispitivanju dejstva negativnih posledica boravka $\mathrm{u}$ zatvoru unutar jedne ustanove ili jednog njenog dela - odeljenja, u našem slučaju se baziralo na utvrđivanje intenziteta deprivacije sigurnosti u četiri različite ustanove za izvršenje kazne zatvora. Odabir ustanova izvršen je s obzirom na kategorizaciju postojećih ustanova zavodskog karaktera. Kao reprezentanti različitih tipova ustanova za ovo istraživanje odabrani su: KPZ Padinska Skela (otvorenog tipa); Okružni zatvor Pančevo (poluotvorenog tipa); KPZ za maloletna i mlađa punoletna lica Valjevo (zatvorenog tipa) i KPZ Požarevac - Zabela (strogo zatvorenog tipa). Ove zatvorske ustanove se međusobno razlikuju po režimu izvršenja kazne, populaciji osuđenih, stepenu liberalizacije/izolacije i strogosti režima. U njima je različit i ukupan režim života i postupanja sa osuđenima. Ukupan položaj osuđenih se razlikuje sa stanovišta obima i vrste posebnih prava koja mogu sticati i koristiti za vreme boravka na izvršenju kazne zatvora. Kako je predviđeno i postojanje različitih odeljenja sa manjim ili većim stepenom obezbeđenja, $\mathrm{u}$ ispitivanoj populaciji nalaze se osuđena lica koja su ili razmeštena fizički u različita odeljenja iste ustanove ili u istoj ustanovi uživaju pogodnosti tokom tretmana koje su predviđene za zatvorena, poluotvorena ili otvorena odeljenja ustanova za izvršenje kazne zatvora. Time prikaz situacije dobija na bogatstvu i opštosti uz poštovanje specifičnosti različitih penalnih ustanova, a ujedno omogućava šire i detaljnije 
sagledavanje negativnih posledica kazne zatvora kod osuđenih i uočavanje faktora nesigurnosti, koji se ne mogu se uočiti posmatranjem samo jedne penalne ustanove.

\section{Varijable istraživanja}

U sagledavanju faktora koji mogu delovati na zavisnu varijablu, u ovom slučaju na stepen prisustva deprivacije sigurnosti, analiziran je veći broj varijabli koje su vezane za neke osnovne karakteristike definisanog uzorka ispitanika. Utvrđivanje ličnih karakteristika je usmereno ka prikupljanju informacija vezanih za demografske (starost, nivo obrazovanja osuđenog lica), socijalno-psihološke (bračno stanje, porodični status pre dolaska na izvršenje kazne zatvora, roditeljstvo), kriminološke (vrsta krivičnog dela, visina izrečene kazne, recidivizam) i penološke karakteristike (raniji boravak u zatvoru, tip ustanove za izvršenje kazne zatvora, tip tretmana, vreme provedeno u zatvoru, vreme do izlaska iz zatvora).

\section{Opis uzorka}

Populaciju ispitanika činila su 183 osuđena muškarca koja su se u vreme ispitivanja nalazila na izvršenju kazne zatvora u KPZ Valjevo, KPZ Padinska Skela, KPZ Požarevac i Okružnom zatvoru Pančevo. Zbog načina ispitivanja zahtevano je da budu pismeni i razumeju/govore srpski jezik. Spektar ispitivanih varijabli zahtevao je zastupljenost osuđenih za različita krivična dela, koji borave u različitim tipovima zatvorskih odeljenja, a zahtevano je učešće i određenog broja recidivista sa iskustvom boravka u penalnim institucijama. Iz tako definisane populacije izvučen je uzorak po modelu prigodnog uzorka. Tako je ostvaren ukupan uzorak od 183 osuđena lica i to: iz KPZ Valjevo 63; iz KPZ Padinska Skela 46; iz KPZ Požarevac-Zabela 58 i iz OZ Pančevo 16 ispitanika.

\section{Struktura ispitanika prema starosti}

U literaturi nalazimo veći broj periodizacija odraslog doba, koje se, kao što navodi Jašović (2000), međusobno razlikuju kako u pogledu broja i starosnih granica pojedinih faza, tako i u pogledu najbitnijih svojstava 
određenih uzrasnih stadijuma. Jašović se opredeljuje za periodizaciju starosnih kategorija koja je prihvaćena i za potrebe ovog istraživanja koja odraslo doba razvrstava na sledeće potfaze: stepen adulacije (18-20 godina), rano zrelo doba (21-30 godina), zrelo doba (30-45 godina), starije zrelo doba (45-60 godina) i doba starosti, preko 65 godina. U skladu sa ovom periodizacijom, ispitanici su podeljeni u pet kategorija.

Posebnu pažnju zavređuju osuđeni u poodmaklom životnom dobu jer zbog svoje fizičke inferiornosti prema mlađim osuđenicima, zbog zdravstvenih problema, invaliditeta i nemoći, često bivaju meta napada, maltretiranja, ponižavanja i sličnih ponašanja koja doprinose intenzivnijem osećanju deprivacije sigurnosti (Jovanić, 2013).

Tabela 1 - Struktura ispitanika prema starosti

\begin{tabular}{|c|c|c|c|c|c|c|c|c|c|c|}
\hline \multirow{3}{*}{$\begin{array}{l}\text { starosna } \\
\text { grupa }\end{array}$} & \multicolumn{10}{|c|}{ KP ZAVOD } \\
\hline & \multicolumn{2}{|c|}{ Valjevo } & \multicolumn{2}{|c|}{ P. Skela } & \multicolumn{2}{|c|}{ Požarevac } & \multicolumn{2}{|c|}{ Pančevo } & \multicolumn{2}{|c|}{ Ukupno } \\
\hline & $\mathrm{br}$ & $\%$ & $\mathrm{br}$ & $\%$ & $\mathrm{Br}$ & $\%$ & br & $\%$ & br & $\%$ \\
\hline do $21 \mathrm{~g}$. & 30 & 47,6 & 6 & 13,0 & - & - & 1 & 6,3 & 37 & 20,2 \\
\hline $22-30 \mathrm{~g}$ & 33 & 52,4 & 22 & 47,8 & 15 & 25,9 & 9 & 56,3 & 79 & 43,2 \\
\hline $31-45 \mathrm{~g}$. & - & - & 12 & 26,1 & 28 & 48,3 & 5 & 31,3 & 45 & 24,6 \\
\hline $46-60 \mathrm{~g}$. & - & - & 3 & 6,5 & 14 & 24,1 & 1 & 6,3 & 18 & 9,8 \\
\hline preko $60 \mathrm{~g}$. & - & - & 3 & 6,5 & 1 & 1,7 & - & - & 4 & 2,2 \\
\hline ukupno & 63 & 34,4 & 46 & 25,1 & 58 & 31,7 & 16 & 8,7 & 183 & 100 \\
\hline
\end{tabular}

$\mathrm{U}$ ispitivanom uzorku, najzastupljenija je starosna grupa 22-30 godina života (43,2\%). Po zastupljenosti slede starosna grupa 31-45 godina života $(24,6 \%)$ i starosna grupa do 21 godine života $(20,2 \%)$. Najmanje je zastupljena starosna grupa osuđenih sa više od 60 godina života $(2,2 \%)$. Ovakva struktura ispitanika podudara se i sa nalazima kriminologa o različitom učešću starosnih grupa u kriminalitetu uopšte (Ignjatović, 2006).

\section{Struktura ispitanika prema obrazovanju}

Nema socijalizacije bez usvajanja kulture i obrazovanja, kao što nema ni obrazovanja koje ne znači socijalizaciju, a samim tim i resocijalizaciju (Jašović, 2000). Otuda i nastojanje da se stepen stečenog obrazovanja sagleda u odnosu na deprivaciju sigurnosti. 
Specijalna edukacija i rehabilitacija (Beograd), Vol. 13, br. 2. 141-172, 2014.

Tabela 2 - Struktura ispitanika prema školskoj spremi

\begin{tabular}{lccccccccccc}
\hline \multirow{3}{*}{ školska sprema } & \multicolumn{10}{c}{ KP ZAVOD } \\
\cline { 2 - 15 } & \multicolumn{1}{c}{ Valjevo } & P. Skela & Požarevac & Pančevo & \multicolumn{2}{c}{ Ukupno } \\
\cline { 2 - 14 } & br & $\%$ & br & $\%$ & br & $\%$ & br & $\%$ & Br & $\%$ \\
\hline nepotpuna osn. škola & 1 & 1,6 & 2 & 4,3 & 3 & 5,2 & 1 & 6,3 & 7 & 3,8 \\
\hline završena osn. škola & 13 & 20,6 & 10 & 21,7 & 10 & 17,2 & 1 & 6,3 & 34 & 18,6 \\
\hline nepotpuna srednja škola & 18 & 28,6 & 8 & 17,4 & 7 & 12,1 & - & - & 33 & 18,0 \\
\hline završena srednja škola & 25 & 39,7 & 14 & 30,4 & 22 & 37,9 & 14 & 87,5 & 75 & 41,0 \\
\hline završen zanat & 6 & 9,5 & 6 & 13,0 & 11 & 19,0 & - & - & 23 & 12,6 \\
\hline visoka šk. sprema & - & - & 6 & 13,0 & 5 & 8,6 & - & - & 11 & 6,0 \\
\hline
\end{tabular}

Po pitanju školske spreme, ispitanici se raspoređuju po principu Gausove krivulje, odnosno ekstremi se pojavljuju najređe, a centralne vrednosti su najizraženije. Sa završenom srednjom školom najviše je ispitanika (41\%). Podjednako su zastupljeni ispitanici sa nezavršenom srednjom (18\%) i završenom osnovnom školom. Završen neki oblik ostručavanja u vidu zanata ima $12,6 \%$ ispitanika, dok visokoobrazovani osuđenici učestvuju sa $6 \%$. Osuđeni sa nepotpunom osnovnom školom su najmanje zastupljeni sa $3,8 \%$ u ispitivanoj populaciji.

Struktura ispitanika prema obrazovanju osuđenih govori da se kriminalitet ne može pripisivati samo neukim, nisko obrazovanim ljudima, već se najčešće u kriminalne aktivnosti upuštaju lica prosečnog obrazovanja. Sličnu konstataciju nalazimo $\mathrm{u}$ istraživanju kriminaliteta maloletnika (Jovanić, Žunić, Ilić, 1999), gde se takođe obrazovna struktura pomera ka centralnim vrednostima, u ovom slučaju ka srednjoj stručnoj spremi.

\section{Bračno stanje ispitanika}

Bračno stanje osuđenih lica je činjenica koja može imati uticaja na ispoljavanje negativnih posledica izvršenja kazne zatvora. Ukoliko se osuđena lica nalaze u braku, uskraćenost kontakata sa bračnim partnerom može uticati i na pojačano ispoljavanje drugih oblika depriviranosti. Često je osuđeni ujedno i hranilac porodice, pa se time situacija pogoršava. Ukupna situacija zavisi i od kvaliteta bračnih odnosa koji su postojali pre dolaska na izvršenje kazne zatvora. Briga za očuvanje bračne zajednice za vreme izvršenja kazne zatvora dodatni je opterećujući faktor za osuđena lica. Dugovremene kazne zatvora su poseban test za bračnu zajednicu. 
Jovanić, G.: (Ne)sigurnost u zatvoru

Tabela 3 - Struktura ispitanika prema bračnom stanju

\begin{tabular}{lcccccccccc}
\hline \multirow{2}{*}{ bračno stanje } & \multicolumn{10}{c}{ KP ZAVOD } \\
\cline { 2 - 14 } & \multicolumn{2}{c}{ Valjevo } & \multicolumn{1}{c}{ P. Skela } & \multicolumn{2}{c}{ Požarevac } & Pančevo & \multicolumn{2}{c}{ Ukupno } \\
\cline { 2 - 13 } & br & $\%$ & br & $\%$ & br & $\%$ & br & $\%$ & br & $\%$ \\
\hline oženjen & 4 & 6,3 & 12 & 26,1 & 17 & 29,3 & 4 & 25,0 & 37 & 20,2 \\
\hline vanbračna zajednica & 8 & 12,7 & 7 & 15,2 & 10 & 17,2 & 3 & 18,8 & 28 & 15,3 \\
\hline neoženjen & 51 & 81,0 & 22 & 47,8 & 15 & 25,9 & 6 & 37,5 & 94 & 51,4 \\
\hline razveden & - & - & 4 & 8,7 & 13 & 22,4 & 2 & 12,5 & 19 & 10,4 \\
\hline udovac & - & - & 1 & 2,2 & 3 & 5,2 & 1 & 6,3 & 5 & 2,7 \\
\hline ukupno & 63 & 34,4 & 46 & 25,1 & 58 & 31,7 & 16 & 8,7 & 183 & 100 \\
\hline
\end{tabular}

Iz Tabele 3 se vidi da je polovina ispitanika neoženjena. Oko trećine je u braku/vanbračnoj zajednici, a nešto više od desetine je ostalo bez bračnog partnera zbog razvoda ili smrti supružnika. Kada se sagleda situacija po kazneno-popravnim zavodima, vidi se da u Valjevu dominiraju (81\%) neoženjeni osuđenici.

Problem bračnosti maloletnika i mlađih punoletnika u tom zatvoru posebno je analiziran 2007. godine (Jovanić, 2007b), jer se na izvršenje kazne upućuju kao maloletnici, odnosno kao mladji punoletnici, pa je i logično očekivati da u toj ustanovi nema razvedenih niti udovaca.

Zapaža se i pravilnost da u zavodima u kojima se izvršava duža kazna zatvora, raste broj razvedenih osuđenika tako da ih je u Padinskoj Skeli 8,7\%; u Pančevu 12,5\%; a u Požarevcu 22,4\% što govori da posledice izvršenja kazne zatvora imaju svog odraza i na (ne)stabilnost bračnih veza.

Poseban problem predstavlja otežano zasnivanje bračnih veza usled vremena provedenog u zatvoru i stigme „bivšeg robijaša”, koja prati osuđeno lice nakon izlaska na slobodu. Negativan stav socijalne sredine prema njima dodatno pogoršava pozicije za naknadnu socijalnu reintegraciju. Odbacivanje od strane socijalne sredine u koju se bivši osuđenik vraća i drugi mehanizmi neformalne socijalne reakcije dodatno im otežavaju integraciju u društvo (Jovanić, 2011a). Dva puta za isto delo mu se ne sudi od strane države (ne bis in idem), ali lokalna sredina, žrtve ili njihove porodice, prijatelji i poznanici izražavaju osudu na svoj način ignorisanjem, odbacivanjem ili čak povređivanjem osuđenog koji izlazi na slobodu. „Halo efekat" ispoljava svoju punu snagu na štetu lica koje tek treba da se integriše u tu zajednicu, pogotovo kod zasnivanja braka. Stoga je ta faza nakon izlaska iz ustanove najosetljiviji deo procesa penalne rehabilitacije i često anulira eventualne pozitivne efekte izvršenja kazne zatvora. 


\section{Struktura ispitanika prema krivičnom delu}

Krivično delo zbog kojeg je osuđenima izrečena zatvorska kazna koristi se u praksi kao jedan od osnova za njihovo razvrstavanje u procesu penalne rehabilitacije i čini bitnu stavku pri izradi individualnog programa postupanja. Prikazani su izvorni odgovori ispitanika, osim u slučaju kategorije „druga krivična dela”, koja je formirana iz praktičnih razloga, radi smanjenja disperzije.

Tabela 4 - Struktura ispitanika prema krivičnim delima

\begin{tabular}{|c|c|c|c|c|c|c|c|c|c|c|}
\hline \multirow{3}{*}{ krivično delo } & \multicolumn{10}{|c|}{ KP ZAVOD } \\
\hline & \multicolumn{2}{|c|}{ Valjevo } & \multicolumn{2}{|c|}{ P. Skela } & \multicolumn{2}{|c|}{ Požarevac } & \multicolumn{2}{|c|}{ Pančevo } & \multicolumn{2}{|c|}{ Ukupno } \\
\hline & $\mathrm{br}$ & $\%$ & $\mathrm{br}$ & $\%$ & $\mathrm{br}$ & $\%$ & br & $\%$ & $\mathrm{br}$ & $\%$ \\
\hline ubistvo & 23 & 36,5 & 2 & 4,3 & 20 & 34,5 & 2 & 12,5 & 47 & 25,7 \\
\hline razbojništvo & 22 & 34,9 & 4 & 8,7 & 10 & 17,2 & 3 & 18,8 & 39 & 21,3 \\
\hline silovanje & 2 & 3,2 & - & - & 2 & 3,4 & 1 & 6,3 & 5 & 2,7 \\
\hline protivpr. blud & - & - & - & - & 1 & 1,7 & 1 & 6,3 & 2 & 1,1 \\
\hline krađa & 1 & 1,6 & 17 & 37,0 & 17 & 29,3 & 3 & 18,8 & 38 & 20,8 \\
\hline saobraćaj & 2 & 3,2 & 6 & 13,0 & 1 & 1,7 & 2 & 12,5 & 11 & 6,0 \\
\hline sticaj kriv.dela & 9 & 14,3 & 3 & 6,5 & 5 & 8,6 & 1 & 6,3 & 18 & 9,8 \\
\hline tel. povrede & 3 & 4,8 & 1 & 2,2 & - & - & 1 & 6,3 & 5 & 2,7 \\
\hline pomoć učiniocu & 1 & 1,6 & 1 & 2,2 & 1 & 1,7 & - & - & 3 & 1,6 \\
\hline oružje & - & - & 2 & 4,3 & 1 & 1,7 & 1 & 6,3 & 4 & 2,2 \\
\hline druga kriv. dela & - & - & 10 & 21,7 & - & - & 1 & 6,3 & 11 & 6,0 \\
\hline ukupno & 63 & 34,4 & 46 & 25,1 & 58 & 31,7 & 16 & 8,7 & 183 & 100,0 \\
\hline
\end{tabular}

Iz Tabele 4 može se zapaziti da su u ispitivanom uzorku najzastupljeniji osuđeni za ubistva (25,7\%), zatim za razbojništva (21,3\%) i krađe (20,8\%). Ti osuđenici čine $67,8 \%$ ispitivanog uzorka. Osuđeni za ostala krivična dela se javljaju u znatno manjem procentu učešća, uvek ispod $10 \%$.

Analiza ovih podataka ukazuje da prikazana struktura krivičnih dela odgovara nalazima drugih autora koji su ispitivali osuđeničku populaciju u penalnim ustanovama (Marić i Radoman, 2001; Ignjatović, 2006, Radovanović, 1992). Preovlađuju imovinska krivična dela (sabrano - razbojništva i krađe čine $42,1 \%$ ), a zatim krivična dela protiv života i tela (ubistva i telesne povrede čine $28,4 \%$ ). Uzete u zbiru, te dve grupe osuđenika čine 70,5\% ukupnog uzorka. Osuđeni za sva druga krivična dela (saobraćaj, seksualni delikti, pomoć učiniocu posle izvršenog krivičnog dela, neovlašćeno držanje oružja, sticaj krivičnih dela i druga krivična dela) čine $29,5 \%$ uzorka. 


\section{Struktura ispitanika prema visini izrečene kazne zatvora}

U razmatranju faktora koji mogu imati uticaja na intenzitet deprivacije sigurnosti, sagledana je i struktura ispitanika prema visini izrečene kazne zatvora. Vremensko određenje budućeg boravka osuđenog u ustanovi, pogotovu kada je reč o dugovremenim kaznama, može uticati na javljanje osećanja besperspektivnosti kod osuđenog i time umanjiti napore ustanove da ga podstakne i motivše na aktivnije učešće u procesu sopstvene resocijalizacije.

Duži boravak nosi sobom rizik učestalijeg izlaganja napadima ostalih osuđenih. S druge strane, kod kratkih kazni zatvora, osuđeno lice ustanovu vidi kao retributivno mesto koje će uskoro napustiti, pa smatra da nema ni potrebu da se aktivnije upušta u aktivnosti u njoj. On teži da prilagodi ponašanje zahtevima ustanove u onoj meri koliko je potrebno da ne bude disciplinski kažnjavan ili da dobije neku od određenih pogodnosti, koje će mu olakšati boravak za vreme izvršenja zatvorske kazne.

Tabela 5 - Struktura ispitanika prema visini izrečene kazne zatvora

\begin{tabular}{|c|c|c|c|c|c|c|c|c|c|c|}
\hline \multirow{3}{*}{$\begin{array}{l}\text { izrečena kazna } \\
\text { zatvora }\end{array}$} & \multicolumn{10}{|c|}{ KP ZAVOD } \\
\hline & \multicolumn{2}{|c|}{ Valjevo } & \multicolumn{2}{|c|}{ P. Skela } & \multicolumn{2}{|c|}{ Požarevac } & \multicolumn{2}{|c|}{ Pančevo } & \multicolumn{2}{|c|}{ Ukupno } \\
\hline & $\mathrm{br}$ & $\%$ & $\mathrm{br}$ & $\%$ & $\mathrm{br}$ & $\%$ & $\mathrm{Br}$ & $\%$ & $\mathrm{br}$ & $\%$ \\
\hline do 6 meseci & - & - & 22 & 47,8 & - & - & 1 & 6,3 & 23 & 12,6 \\
\hline 6 mes. do $1 \mathrm{~g}$. & - & - & 16 & 34,8 & 3 & 5,2 & 4 & 25,2 & 24 & 13,1 \\
\hline 1-5 godina & 31 & 49,2 & 8 & 17,4 & 21 & 36,2 & 7 & 43,8 & 66 & 36,1 \\
\hline 5-10 godina & 32 & 50,8 & - & - & 13 & 22,4 & 3 & 18,8 & 48 & 26,2 \\
\hline preko $10 \mathrm{~g}$. & - & - & - & - & 21 & 36,2 & 1 & 6,3 & 22 & 12,0 \\
\hline ukupno & 63 & 34,4 & 46 & 25,1 & 58 & 31,7 & 16 & 8,7 & 183 & 100 \\
\hline
\end{tabular}

Iz Tabele 5 može se zapaziti da se najveći broj osuđenih iz uzorka nalazi u grupi izrečenih zatvorskih kazni u trajanju od 1 do 5 godina $(36,1 \%)$ odnosno od 5 do 10 godina (26,2\%). U podjednakoj meri učestvuju osuđenici sa izrečenom kaznom zatvora u trajanju od 6 meseci do 1 godine $(13,1 \%)$, do 6 meseci $(13,1 \%)$ i preko 10 godina (12\%).

Odstupanja od rasporednog rešenja kojim se osuđena lica razmeštaju u Zavode prema visini izrečene kazne zatvora, kao jednog od kriterijuma, zapažena su u OKZ Pančevo, ali je objašnjeno da je ta situacija nastala njihovim razmeštanjem u druge ustanove kako bi se sačuvala bezbednosna situacija u Zavodima iz kojih su razmešteni. 
Takva praksa, sa prevaspitnog aspekta, nanosi više štete no koristi jer se narušava princip formiranja vaspitnih grupa u skladu sa potrebama tretmana i odvajanja različitih kategorija osuđenika. Naknadno raspoređeni osuđenici iz drugih KPZ nastoje da se nametnu kao lideri neformalnog osuđeničkog sistema. Pogotovu ako dolaze iz KPZ zatvorenog ili strogo zatvorenog tipa. Oni se nameću najčešće ugrožavanjem drugih osuđenih, nepoštovanjem formalnih pravila u ustanovi i formiranjem novih grupa osuđenika koji se suprotstavljaju postojećem neformalnom sistemu u borbi za premoć. Istovremeno se narušava bezbednost drugih osuđenih u ustanovama gde se takvi osuđenici naknadno raspoređuju. Sem toga, nanovo se započinje proces adaptacije i integracije osuđenog na novu zavodsku situaciju. Sve to može dovesti do pojačanog prisustva deprivacije sigurnosti.

\section{Struktura ispitanika prema odeljenju - vrsti tretmana}

Zatvorenost odeljenja, tj. vrsta tretmana u okviru ustanove u kojoj se izvršava kazna zatvora, jedna je od činjenica koja zavisi i od razmeštaja osuđenih za koje se pretpostavlja da zbog svoje agresivnosti, društvene opasnosti i neadaptacije na zatvorski režim mogu remetiti svakodnevni život u zatvorskoj sredini, pa se raspoređuju u zatvoreniji oblik tretmana. To ujedno može imati odraza i na intenzitet deprivacije sigurnosti jer boravak sa njima $\mathrm{u}$ istom prostoru kod drugih osuđenih izaziva anksioznost i tenzije.

Tabela 6 - Struktura ispitanika prema tretmanu / odeljenju

\begin{tabular}{lcccccccccc}
\hline \multirow{2}{*}{ tretman/odeljenje } & \multicolumn{10}{c}{ KP ZAVOD } \\
\cline { 2 - 14 } & \multicolumn{1}{c}{ Valjevo } & \multicolumn{10}{c}{ P. Skela } & \multicolumn{1}{c}{ Požarevac } & \multicolumn{2}{c}{ Pančevo } & \multicolumn{2}{c}{ Ukupno } \\
\cline { 2 - 13 } & br & br & $\%$ & br & $\%$ & br & $\%$ & br & $\%$ \\
\hline otvoren & - & - & 14 & 30,5 & 1 & 1,7 & 1 & 6,3 & 16 & 8,7 \\
\hline poluotvoren & 16 & 25,4 & 25 & 54,3 & 6 & 10,3 & 7 & 73,8 & 54 & 29,5 \\
\hline zatvoren & 47 & 74,6 & 7 & 15,2 & 41 & 70,7 & 8 & 50,0 & 103 & 56,3 \\
\hline strogo zatvoren & - & - & - & - & 10 & 17,2 & - & - & 10 & 5,5 \\
\hline ukupno & 63 & 34,4 & 46 & 25,1 & 58 & 31,7 & 16 & 8,7 & 183 & 100,0 \\
\hline
\end{tabular}

Analiza Tabele 6 pokazuje da je u ispitivanom uzorku najviše osuđenika pod režimom izvršenja kazne zatvora u zatvorenom (56\%) odeljenju/ tretmanu, u poluotvorenom ih je $29,5 \%$, u otvorenom $8,7 \%$, a najmanje ih je iz strogo zatvorenog odeljenja/tretmana.

U KPZ Padinska Skela najviše ispitanika je u poluotvorenom tretmanu (54,3\%), manje ih je u otvorenom (30,5\%), a najmanje u zatvorenom 
tretmanu (15,2\%), što nije razumljivo s obzirom da je to Zavod otvorenog tipa. Ako i otvorena ustanova ima primenu zatvorenog tretmana, a s druge strane strogo zatvorena ustanova (kao što je KPZ Požarevac) primenu otvorenog i polotvorenog tretmana, činjenica je da nema „čiste” ustanove po kriterijumu zatvorenosti. Kakva je svrha kategorizacije ustanova ako svaka od njih služi za izvršenje kazne zatvora svih kategorija osuđenika?

Objašnjenja su raznolika, ali je evidentno da se nedoslednost $u$ tom pogledu javlja kao otežavajući faktor organizovanju procesa penalne rehabilitacije. Sa stanovišta prisustva negativnih posledica izvršenja ovakvo heterogeno rešenje nije poželjno. Zakonodavčeva intencija da ustanova otvorenog tipa služi za izvršenje zatvorske kazne prema osuđenima manjeg stepena društvene opasnosti očigledno ne funkcioniše. Postavlja se pitanje i opravdanosti postojanja zatvorenog i poluotvorenog tretmana $\mathrm{u}$ takvoj ustanovi i raspoređivanja osuđenih koji nisu za takav tip ustanove.

\section{Struktura ispitanika prema vremenu boravka u zatvoru}

Duža izloženost uticajima koji vladaju u zatvorskom ambijentu može, $s$ jedne strane, stvoriti intenzivnije osećanje depriviranosti, a s druge strane, može delovati suprotno, tj. da se osuđeno lice vremenom privikava na uslove zatvorske životne situacije. Usled toga se može pojaviti i fenomen prizonizacije na totalitarnu ustanovu i umanjene sposobnosti kasnijeg privikavanja na uslove života u slobodnom svetu.

Tabela 7 - Struktura ispitanika prema vremenu boravka u KPU

\begin{tabular}{|c|c|c|c|c|c|c|c|c|c|c|}
\hline \multirow{3}{*}{$\begin{array}{l}\text { vreme provedeno } \\
\text { u KPZ }\end{array}$} & \multicolumn{10}{|c|}{ KP ZAVOD } \\
\hline & \multicolumn{2}{|c|}{ Valjevo } & \multicolumn{2}{|c|}{ P. Skela } & \multicolumn{2}{|c|}{ Požarevac } & \multicolumn{2}{|c|}{ Pančevo } & \multicolumn{2}{|c|}{ Ukupno } \\
\hline & $\mathrm{br}$ & $\%$ & $\mathrm{br}$ & $\%$ & $\mathrm{br}$ & $\%$ & $\mathrm{br}$ & $\%$ & $\mathrm{br}$ & $\%$ \\
\hline do 6 meseci & 11 & 17,5 & 39 & 84,8 & 13 & 22,4 & 8 & 50,0 & 71 & 38,8 \\
\hline 7 mes. - 1 god. & 11 & 17,5 & 3 & 6,5 & 7 & 12,1 & 2 & 12,5 & 23 & 12,6 \\
\hline 13 mes. - 3 god. & 24 & 38,1 & 4 & 8,7 & 20 & 34,5 & 2 & 12,5 & 50 & 27,3 \\
\hline preko 3 godine & 17 & 27,0 & - & - & 18 & 31,0 & 4 & 25,0 & 39 & 21,3 \\
\hline ukupno & 63 & 34,4 & 46 & 25,1 & 58 & 31,7 & 16 & 8,7 & 183 & 100 \\
\hline
\end{tabular}

Iz Tabele 7 može se zapaziti da se u uzorku nalazi najviše ispitanika koji su na izvršenju kazne zatvora proveli manje od 6 meseci (38,8\%). Slede osuđenici koji su u ustanovi proveli više od jedne, a manje od 3 godine (27,3\%). Nakon njih, po zastupljenosti slede osuđenici koji su u ustanovi 
više od 3 godine (petina), a najmanje je onih koji su u ustanovi proveli više od 6 meseci, a manje od godinu dana (12,6\%).

S obzirom da je KPZ Padinska Skela ustanova za izvršenje tzv. kraćih zatvorskih kazni, ne čudi što se u toj ustanovi struktura osuđenika znatno razlikuje od ostalih. Jedino u toj ustanovi nema osuđenika sa više od tri godine boravka. To bi trebalo da bude slučaj i sa OKZ Pančevo, ali iz razloga razmeštanja osuđenih iz drugih ustanova zatekli smo i osuđene sa dužim boravkom od tri godine.

\section{Struktura ispitanika prema prethodnoj osudivanosti}

Prethodna osuđivanost nekog lica je činjenica koja može imati značaja za temu istraživanja u smislu ukazivanja na sklonost lica da vrši ponovo krivična dela i nakon prethodno izvršene krivične sankcije. Specijalno preventivni efekti su izostali i lice se ovaj put nalazi na izvršenju zatvorske kazne. To podrazumeva i preduzimanje intenzivnijih mera i postupaka u penalnom tretmanu, imajući u vidu da se radi o recidivistima. Sa aspekta pojave negativnih posledica izvršenja kazne zatvora, osoba se ponovo susreće sa pravosudnim organima, način reagovanja na deprivacionu situaciju se ponovo proživljava.

Tabela 8 - Struktura ispitanika prema prethodnoj osudivanosti

\begin{tabular}{|c|c|c|c|c|c|c|c|c|c|c|}
\hline \multirow{3}{*}{$\begin{array}{l}\text { prethodna } \\
\text { osuđivanost }\end{array}$} & \multicolumn{10}{|c|}{ KP ZAVOD } \\
\hline & \multicolumn{2}{|c|}{ Valjevo } & \multicolumn{2}{|c|}{ P. Skela } & \multicolumn{2}{|c|}{ Požarevac } & \multicolumn{2}{|c|}{ Pančevo } & \multicolumn{2}{|c|}{ Ukupno } \\
\hline & $\mathrm{br}$ & $\%$ & $\mathrm{br}$ & $\%$ & $\mathrm{br}$ & $\%$ & $\mathrm{br}$ & $\%$ & $\mathrm{br}$ & $\%$ \\
\hline primarna kazna & 46 & 73,0 & 23 & 50,0 & 25 & 43,1 & 13 & 81,3 & 107 & 58,5 \\
\hline recidivisti & 17 & 27,0 & 23 & 50,0 & 33 & 56,9 & 3 & 18,8 & 76 & 41,5 \\
\hline ukupno & 63 & 34,4 & 46 & 25,1 & 58 & 31,7 & 16 & 8,7 & 183 & 100 \\
\hline
\end{tabular}

Podaci iz Tabele 8 ukazuju na činjenicu da je u ispitivanom uzorku učestvovalo nešto više legalnih recidivista $(58,5 \%)$, a nešto manje su učestvovala primarno osuđena lica prema kojima je prvi put izrečena neka od krivičnopravnih sankcija (41,5\%).

Činjenica je da se recidivizam javlja kao problem, s obzirom da se radi o licima sklonim da ponavljaju činjenje krivičnih dela. Situacija je složenija time što se radi o $30 \%$ lica kojima je zatvorska kazna izrečena kao prva krivična sankcija. Drugih 30\% recidivista su već imali prethodno iskustvo izvršenja kazne zatvora. 
Ukoliko bi se problem recidivizma želeo povezati sa nefunkcionisanjem sistema izvršenja zatvorske kazne, $\mathrm{u}$ istoj meri bi se mogao kritikovati i sistem izvršenja svih drugih krivičnih sankcija. Kazne kao kazne nisu funkcionisale ni kod zatvora ni kod ostalih krivičnih sankcija u 30\% slučajeva. Tako se ukazuje potreba preispitivanja celokupnog pravosudnog sistema (Jovanić, 2011b), ali i drugih sistema iz oblasti rada, zapošljavanja, socijalnog staranja... koji bi trebalo funkcionisati i generalno preventivno i specijalno preventivno, naročito u sistemu postpenalne pomoći.

\section{Struktura ispitanika prema penološkom recidivizmu}

Ponovni dolazak istog lica u penalnu ustanovu ima nešto veći značaj za problem ispitivanja negativnih posledica izvršenja kazne zatvora nego prethodna osuđivanost jer se u ovom slučaju radi o ponovnom dolasku u ustanovu radi izvršenja kazne zatvora. To ujedno znači da su penološki recidivisti već jednom (a neki i više puta) prošli sve faze boravka u zatvoru (Jovanić, 2010a). Oni su upoznati sa pravilima ponašanja, zahtevima uprave, formalnim i neformalnim organizacijama koje vladaju unutar zatvora, mogućnostima i načinima da se što bolje adaptiraju na uslove života i na taj način ublaže depriviranost. Kod lica koji prvi put dolaze na izvršenje zatvorske kazne prisutne su određene nedoumice, predrasude i strahovi. Zatvorsko životno okruženje je novi životni okvir u kome se najčešće ne snalaze, u kome tek treba da se dokažu, opstanu, prežive i dočekaju živi i zdravi izlazak na slobodu.

Tabela 9 - Struktura ispitanika prema penološkom recidivizmu

\begin{tabular}{lcccccccccc}
\hline \multirow{2}{*}{$\begin{array}{l}\text { penološki } \\
\text { recidivizam }\end{array}$} & \multicolumn{10}{c}{ KP ZAVOD } \\
\cline { 2 - 13 } & \multicolumn{2}{c}{ Valjevo } & \multicolumn{1}{c}{ P. Skela } & \multicolumn{1}{c}{ Požarevac } & \multicolumn{2}{c}{ Pančevo } & \multicolumn{2}{c}{ Ukupno } \\
\cline { 2 - 12 } & br & $\%$ & br & $\%$ & br & $\%$ & br & $\%$ & br & $\%$ \\
\hline primarno zatvaranje & 55 & 87,3 & 34 & 73,9 & 30 & 51,7 & 10 & 62,5 & 129 & 70,5 \\
\hline penološki recidivist & 8 & 12,7 & 12 & 26,1 & 28 & 48,3 & 6 & 37,5 & 54 & 29,5 \\
\hline ukupno & 63 & 34,4 & 46 & 25,1 & 58 & 31,7 & 16 & 8,7 & 183 & 100 \\
\hline
\end{tabular}

Iz Tabele 9 vidi se da je u strukturi ispitanika preovlađujuća grupa osuđenika koja se prvi put nalazi na izvršenju kazne zatvora (70,5\%), u odnosu na penološke recidiviste (29,5\%). Najveća zastupljenost penoloških recidivista zapaža se u KPZ Požarevac (oko polovine) u odnosu na druge ustanove. U Padinskoj Skeli takvih je više od četvrtine, a u Pančevu više od trećine. 
U upitniku je definisano da se pod penološkim recidivizmom smatra i prethodno izvršenje vaspitne mere upućivanja u vaspitno popravni dom, pa se tako zapaža da i u KPZ Valjevo ima onih koji su prethodno imali iskustva sa ustanovama za izvršenje krivičnih sankcija, a samim tim i sa specifičnim uslovima života u totalitarnim ustanovama (12,7\%).

Prisustvo penoloških recidivista u KPZ Padinska Skela (preko četvrtine), u ustanovi namenjenoj primarno osuđenim licima predstavlja otežavajući faktor za organizaciju procesa prevaspitanja, o kome se pri raspoređivanju osuđenih izgleda manje vodi računa (Ilić, Jovanić, 2009). Sa stanovišta pojave negativnih posledica izvršenja kazne zatvora, prisustvo recidivista pojačava tenziju među ostalim osuđenicima. Problemi tzv. „kriminalne infekcije", jačanja neformalnog sistema, ugnjetavanja slabijih, starijih i neiskusnih su u takvim okolnostima verovatniji (Jovanić, 2010b).

\section{Instrumenti}

U cilju prikupljanja empirijskih podataka, ispitanici su anketirani opštim upitnikom (kojim su prikupljeni podaci o varijablama vezanim za osnovne demografske, kriminološko-penološke i socijalno-psihološke podatke) i Skalom za ispitivanje depriviranosti osuđenih lica deprivacijom sigurnosti (SIG), standardizovanom od strane Instituta za kriminološka i sociološka istraživanja u Beogradu. Ovaj instrument korišćen je ranije u istraživanju zatvorske neformalne zajednice (Radovanović, 1992). Pokazao je visok nivo interne konzistentnosti (Cronbach's $\alpha=0,952$ ) u našem istraživanju. SIG skala ima 34 pitanja i rađena je po principu Likertove skale. Osuđenima su ponuđene mogućnosti izjašnjavanja od „potpuno netačno" $=1$; „donekle netačno” $=2$; „nisam siguran” $=3$; „donekle tačno” $=4$; do kategorije „potpuno tačno" $=5$.

$\mathrm{Na}$ taj način dobijeni skorovi su kategorisani tako što su od maksimalno mogućih 170 poena (34x5) raspodeljeni u tri grupe odgovora koji podrazumevaju tri nivoa depriviranosti:

- u prvu kategoriju depriviranosti, „nizak nivo depriviranosti”, svrstani su ispitanici koji su na skali deprivacije postigli do 55 poena; 
- u drugu kategoriju depriviranosti, „povišen nivo depriviranosti”, svrstani su ispitanici koji su na skali deprivacije postigli od 56 do 110 poena $\mathrm{i}$

- u treću kategoriju depriviranosti, „visok nivo depriviranosti”, svrstani su ispitanci koji su na skali deprivacije postigli preko 111 poena.

Skala je i konstruisana tako da veći skor označava ujedno i viši nivo depriviranosti.

\section{Statistička obrada podataka}

Podaci o ispitivanim karakteristikama osuđenih lica, kvalitetu i intenzitetu deprivacije sigurnosti prikazani su u apsolutnim i relativnim vrednostima, a za utvrđivanje značajnosti odnosa među varijablama primenjen je koeficijent korelacije.

\section{REZULTATI ISTRAŽIVANJA}

Nakon prikaza strukture ispitanika prema osnovnim demografskim, socijalno-psihološkim i kriminološko-penološkim karakteristikama, ispitivani su prisustvo i intenzitet deprivacije sigurnosti i povezanost između te zavisne varijable i navedenih karakteristika. Analizom je ujedno utvrđivan kvalitet i kvantitet deprivacije sigurnosti kod osuđenih lica u različitim ustanovama, u njihovim odeljenjima i s obzirom na lična svojstva osuđenih.

\section{Deprivacija sigurnosti i tip ustanove za izvršenje kazne zatvora}

U skladu sa postavljenim ciljevima istraživanja, ispitivali smo povezanost tipa zatvorske ustanove sa intenzitetom deprivacije sigurnosti. U zavode sa većim stepenom obezbeđenja i strožim režimom izvršenja kazne zatvora upućuju se lica koja po karakteristikama ličnosti i težini krivičnog dela predstavljaju veći problem. Zahtevi kontrole, nadzora i izolacije u odnosu na njih su veći nego u odnosu na lica koja se upućuju u ustanove poluotvorenog i otvorenog tipa. Stoga je tip ustanove u kojoj se izvršava 
kazna zatvora uzet kao faktor u razmatranju eventualnog uticaja na pojavu deprivacije sigurnosti.

Tabela 10 - Deprivacija sigurnosti i tip KPU

\begin{tabular}{|c|c|c|c|c|c|c|c|c|}
\hline \multirow{3}{*}{ KP ZAVOD } & \multicolumn{8}{|c|}{ DEPRIVACIJA SIGURNOSTI } \\
\hline & \multicolumn{2}{|c|}{$\begin{array}{c}\text { nizak nivo } \\
\text { depriviranosti }\end{array}$} & \multicolumn{2}{|c|}{$\begin{array}{l}\text { povišen nivo } \\
\text { depriviranosti }\end{array}$} & \multicolumn{2}{|c|}{$\begin{array}{c}\text { visok nivo } \\
\text { depriviranosti }\end{array}$} & \multicolumn{2}{|c|}{ ukupno } \\
\hline & $\mathrm{br}$ & $\%$ & $\mathrm{br}$ & $\%$ & $\mathrm{br}$ & $\%$ & $\mathrm{br}$ & $\%$ \\
\hline Požarevac & 5 & 8,6 & 31 & 53,4 & 22 & 37,9 & 58 & 31,7 \\
\hline Valjevo & 10 & 15,9 & 37 & 58,7 & 16 & 25,4 & 63 & 34,4 \\
\hline Pančevo & 2 & 12,5 & 8 & 50,0 & 6 & 37,5 & 16 & 8,7 \\
\hline Pad. Skela & 10 & 21,7 & 28 & 60,9 & 8 & 17,4 & 46 & 25,1 \\
\hline ukupno & 27 & 14,8 & 104 & 56,8 & 52 & 28,4 & 183 & 100,0 \\
\hline
\end{tabular}

Koncentracija odgovora ispitanika je usmerena na povišen nivo deprivacije $(56,8 \%)$, dok visok nivo depriviranosti iskazuje $28,4 \%$ a odsustvo depriviranosti $14,8 \%$ osuđenih. Visok nivo deprivacije sigurnosti ispoljavaju osuđeni u KPZ Požarevac i OKZ Panačevo (oko 38\%). Nižu učestalost (oko četvrtine) odgovora visoke depriviranosti iskazuju osuđeni u KPZ Valjevo, a najnižu (17,4\%) u KPZ Padinska Skela.

To bi globalno i odgovaralo uvreženom stavu da se u zatvorenijim ustanovama osuđena lica osećaju manje sigurno, ali tu logiku narušavaju odgovori osuđenih koji iskazuju povišen nivo depriviranosti, jer su u otvorenoj ustanovi najčešći takvi odgovori (61\%). U svim posmatranim ustanovama učestalost odgovora osuđenih da su povišeno deprivirani prelazi polovinu odgovora. Najveće odsustvo depriviranosti je po očekivanju u KPZ Padinska Skela (petina), potom u KPZ Valjevo (16\%), OKZ Pančevo $(12,5 \%)$, a najniže u KPZ Požarevac (8,6\%).

Može se zaključiti da deprivacija sigurnosti pogađa osuđena lica u svim kategorijama ustanova za izvršenje kazne zatvora. Stepen prisustva deprivacije sigurnosti ne korelira sa stepenom zatvorenosti ustanova $(\mathrm{p}=0,143)$. Zatvori nisu mesto gde se osuđeni osećaju bezbedno i sigurno, pa makar se zvali i otvoreni.

\section{Deprivacija sigurnosti i vrsta odeljenja-tretmana}

U okviru posmatranih zatvora razlikuju se režimi izvršenja po stepenu prava, pogodnosti, ograničenja i ukupnog odnosa prema osuđenom, 
zavisno od vrste odeljenja ili tretmana koji je uži okvir izvršenja kazne zatvora. Stoga je taj faktor uzet u analizu u određivanju njegovog odnosa prema deprivaciji sigurnosti.

Tabela 11 - Deprivacija sigurnosti i vrsta odeljenja-tretmana

\begin{tabular}{lcccccccc}
\hline \multirow{2}{*}{$\begin{array}{l}\text { TRETMAN } \\
\text { ODELJENJE }\end{array}$} & $\begin{array}{c}\text { nizak nivo } \\
\text { deprviranosti }\end{array}$ & \multicolumn{2}{c}{$\begin{array}{c}\text { povišen nivo } \\
\text { depriviranosti }\end{array}$} & $\begin{array}{c}\text { visok nivo } \\
\text { depriviranosti }\end{array}$ & \multicolumn{2}{c}{ ukupno } \\
\cline { 2 - 11 } & br & $\%$ & br & $\%$ & br & $\%$ & br & $\%$ \\
\hline otvoreni & 4 & 25,0 & 7 & 43,8 & 5 & 31,3 & 16 & 8,7 \\
\hline poluotvoreni & 9 & 16,7 & 32 & 59,3 & 13 & 24,1 & 54 & 29,5 \\
\hline zatvoreni & 13 & 12,6 & 61 & 59,2 & 29 & 28,2 & 103 & 56,3 \\
\hline strogo zatvoreni & 1 & 10,0 & 4 & 40,0 & 5 & 50,0 & 10 & 5,5 \\
\hline ukupno & 27 & 14,8 & 104 & 56,8 & 52 & 28,4 & 183 & 100,0 \\
\hline
\end{tabular}

Uvid u Tabelu 11 pokazuje da je procenat nisko depriviranih u porastu sa povećanjem otvorenosti odeljenja-tretmana. $S$ druge strane raste učešće odgovora koji označavaju visoku depriviranost sa porastom zatvorenosti odeljenja-tretmana. Izuzetak čini otvoreno odeljenje-tretman gde se osuđeni češće izjašnjavaju da su visoko deprivirani od osuđenih iz poluotvorenog i zatvorenog odeljenja-tretmana.

Najzastupljenija je centralna kategorija koja označava povišenu depriviranost (56,8\%), manje je zastupljen visok stepen depriviranosti $(28,4 \%)$, a najmanje je zastupljen nizak stepen deprivacije sigurnosti (14,8\%). Takva distribucija odgovora je razlog zbog kojeg nije ustanovljena statistički značajna korelacija ukrštanih varijabli $(\mathrm{p}=0,558)$.

Može se konstatovati da su osuđena lica pogođena deprivacijom sigurnosti, a stepen depriviranosti ne zavisi od vrste odeljenja-tretmana u kojem se nalaze za vreme izvršenja kazne zatvora.

\section{Deprivacija sigurnosti i krivično delo}

Izvršenje zatvorske kazne neminovno je takvo da se $\mathrm{u}$ istoj ustanovi nalaze osuđena lica za različita krivičnih dela. Osuđeni se razlikuju po motivu, sredstvima, okolnostima činjenja krivičnih dela. Razlikuju se i po odnosu prema žrtvi, delu, ostvarenim posledicama po okolinu i sebe. Očekivanja su išla u pravcu da će osuđeni za lakša krivična dela ispoljavati 
viši stepen deprivacije sigurnosti, u odnosu na osuđene za teža krivična dela.

Tabela 12 - Deprivacija sigurnosti i krivično delo

\begin{tabular}{lcccccccc}
\hline & \multicolumn{7}{c}{ DEPRIVACIJA SIGURNOSTI } \\
\cline { 2 - 10 } krivično delo & $\begin{array}{c}\text { nizak nivo } \\
\text { deprviranosti }\end{array}$ & \multicolumn{2}{c}{ povišen nivo } & \multicolumn{2}{c}{ visok nivo } \\
depriviranosti & depriviranosti & \multicolumn{2}{c}{ ukupno } \\
\cline { 2 - 11 } & br & $\%$ & br & $\%$ & br & $\%$ & br & $\%$ \\
\hline ubistvo & 7 & 14,9 & 25 & 53,2 & 15 & 31,9 & 47 & 25,7 \\
\hline razbojništvo & 6 & 15,4 & 23 & 59,0 & 10 & 25,6 & 39 & 21,3 \\
\hline silovanje & - & - & 4 & 80,0 & 1 & 20,0 & 5 & 2,7 \\
\hline pp blud & - & - & 1 & 50,0 & 1 & 50,0 & 2 & 1,1 \\
\hline krađa & 2 & 5,3 & 26 & 68,4 & 10 & 26,3 & 38 & 20,8 \\
\hline saobraćaj & 1 & 9,1 & 5 & 45,5 & 5 & 45,5 & 11 & 6,0 \\
\hline sticaj dela & 2 & 11,1 & 11 & 61,1 & 5 & 27,8 & 18 & 9,8 \\
\hline tel. povrede & 2 & 40,0 & 2 & 40,0 & 1 & 20,0 & 5 & 2,7 \\
\hline pomoć učiniocu & - & - & 2 & 66,6 & 1 & 33,3 & 3 & 1,6 \\
\hline oružje & 1 & 25,0 & 1 & 25,0 & 2 & 50,0 & 4 & 2,2 \\
\hline druga kriv. dela & 6 & 54,5 & 4 & 36,4 & 1 & 9,1 & 11 & 6,0 \\
\hline ukupno & 27 & 14,8 & 104 & 56,8 & 52 & 28,4 & 183 & 100,0 \\
\hline
\end{tabular}

Razuđenost klasifikacije osuđenih prema pojedinačnim krivičnim delima, kojom se distribucija frekvencije raspršuje tako da je analiza prema malom broju pripadnika određene kategorije nedovoljno sigurna, a zaključak donesen na osnovu koeficijenta korelacije $(\mathrm{p}=0,093)$, ne daje materijala za decidniju analizu.

Evidentna činjenica je da mali broj osuđenih oseća sigurnost za vreme boravka u zatvoru (u proseku 14,8\%). Jedino se u tom pogledu izdvajaju osuđeni za „druga krivična dela”, ali je i to raznorodna skupina, što onemogućava preciznije razmatranje.

Osuđeni za seksualne delikte ne iskazuju ni u jednom slučaju nizak nivo depriviranosti. Taj podatak ide u prilog tvrdnji da ih ne tolerišu ni druga osuđena lica. Činjenica je da u mikrosvetu osuđenih niko nikog ne toleriše i da se međusobno ugnjetavaju bez obzira na vrstu zločina koji su počinili. Kategoriju visoke depriviranosti iskazali su (sporadično) osuđeni iz svih kategorija krivičnih dela. Osuđeni u zatvoru konstantno strepe od drugih osuđenih sa kojima dele životni prostor, nezavisno od krivičnog dela za koje im je izrečena zatvorska kazna. Hobsova izreka homo homini lupus u zatvoru ima stvarno životno značenje. 


\section{Deprivacija sigurnosti i visina izrečene kazne}

Visina izrečene kazne zatvora je faktor koji je dovođen u vezu sa deprivacijom sigurnosti, jer osuđeni na duže kazne uobičajeno važe za one koje treba izbegavati i sa njima se ne sukobljavati.

Tabela 13 - Deprivacija sigurnosti i visina izrečene kazne

\begin{tabular}{lcccccccc}
\hline \multirow{2}{*}{$\begin{array}{l}\text { visina izrečene } \\
\text { kazne }\end{array}$} & $\begin{array}{c}\text { nizak nivo } \\
\text { deprviranosti }\end{array}$ & \multicolumn{2}{c}{ povišen nivo } & depriviranosti & \multicolumn{2}{c}{$\begin{array}{c}\text { visok nivo } \\
\text { depriviranosti }\end{array}$} & \multicolumn{2}{c}{ ukupno } \\
\cline { 2 - 10 } & br & $\%$ & br & $\%$ & br & $\%$ & br & $\%$ \\
\hline do 6 meseci & 5 & 21,7 & 14 & 60,9 & 4 & 17,4 & 23 & 12,6 \\
\hline 6 mes. do 1 g. & 3 & 12,5 & 15 & 62,5 & 6 & 25,0 & 24 & 13,1 \\
\hline 1-5 godina & 9 & 13,6 & 35 & 53,0 & 22 & 33,3 & 66 & 36,1 \\
\hline 5-10 godina & 8 & 16,7 & 29 & 60,4 & 11 & 22,9 & 48 & 26,2 \\
\hline preko 10 g. & 2 & 9,1 & 11 & 50,0 & 9 & 40,9 & 22 & 12,0 \\
\hline ukupno & 27 & 14,8 & 104 & 56,8 & 52 & 28,4 & 183 & 100 \\
\hline
\end{tabular}

Kao što se može videti iz podataka u Tabeli 13 , najniži nivo deprivranosti iskazuju najčešće lica osuđena na najkraće kazne, a najviši nivo depriviranosti najčešće iskazuju lica osuđena na najduže kazne. Najveća koncentracija odgovora ispitanika iz svih kategorija je u domenu povišenog nivoa depriviranosti (uvek preko polovine), tako da se i ovde može reći da deprivacija sigurnosti pogađa sve osuđene nezavisno od visine izrečene kazne zatvora. Ni ovaj faktor se nije pokazao kao statistički značajan korelant deprivaciji sigurnosti $(\mathrm{p}=0,386)$.

\section{Deprivacija sigurnosti i vreme provedeno u KPU}

Osuđeni sa dužim vremenom provedenim u ustanovi važe za privilegovane unutar osuđeničkog kolektiva, dok se novopridošli osuđenici stavljaju u test situacije. Oni još uvek nisu ostvarili čvršće veze i kontakte sa ostalim osuđenicima. Nedostaju snažnije veze koje bi im obezbedile sigurniji status u zatvorskim uslovima. 
Specijalna edukacija i rehabilitacija (Beograd), Vol. 13, br. 2. 141-172, 2014.

Tabela 14 - Deprivacija sigurnosti i vreme provedeno u KPU

\begin{tabular}{lcccccccc}
\hline \multirow{2}{*}{$\begin{array}{l}\text { vreme provedeno } \\
\text { u KPU }\end{array}$} & \multicolumn{7}{c}{ nizak nivo } & \multicolumn{2}{c}{ povišen nivo } & \multicolumn{2}{c}{ visok nivo } & \multicolumn{2}{c}{ ukupno } \\
\cline { 2 - 10 } & deprviranosti & depriviranosti & depriviranosti & \multicolumn{2}{c}{ de } \\
\cline { 2 - 10 } & br & $\%$ & br & $\%$ & br & $\%$ & br & $\%$ \\
\hline do 6 meseci & 12 & 16,9 & 41 & 57,7 & 18 & 25,4 & 71 & 38,8 \\
\hline 7 meseci do 1 god. & 4 & 17,4 & 9 & 39,1 & 10 & 43,5 & 23 & 12,6 \\
\hline 13 meseci do 3 god. & 3 & 6,0 & 33 & 66,0 & 14 & 28,0 & 50 & 27,3 \\
\hline preko 3 godine & 8 & 20,5 & 21 & 53,8 & 10 & 25,6 & 39 & 21,3 \\
\hline ukupno & 27 & 14,8 & 104 & 56,8 & 52 & 28,4 & 183 & 100 \\
\hline
\end{tabular}

Podaci iz Tabele 14 pokazuju da nema većih razlika između odgovora koji označavaju visok stepen prisustva deprivacije sigurnosti, sem kod kategorije osuđenih koji se u ustanovama nalaze više od 6 meseci, a manje od 1 godine. Kod njih je to učešće najveće $(43,5 \%)$, dok se ostale kategorije izjašnjavaju sa podjednakom učestalošću (oko četvrtine).

Najbezbednije se osećaju osuđeni koji su u ustanovama preko 3 godine (petina), dok najniže učešće u toj kategoriji odgovora ostvaruju osuđeni koji u ustanovama borave od 1 do 3 godine (6\%). Osim kategorije osuđenih koji borave u ustanovama više od 6 meseci, a manje od 1 godine, kod svih drugih kategorija osuđenika najzastupljeniji su odgovori koji označavaju povišen stepen depriviranosti usled osećanja nesigurnosti i to preko polovine učešča odgovora, pa do dve trećine. Usled ovakve neravnomerne distribucije odgovora, nije utvrđena statistički značajna korelacija ukrštanih varijabli $(\mathrm{p}=0,941)$.

Može se zaključiti da deprivacija sigurnosti pogađa osuđene bez obzira na vreme koje su proveli u zatvoru. Osuđeni se osećaju nebezbedno u zatvoru, ma koliko dugo u njemu boravili. Paradoks je da zatvori, koji treba da obezbede sigurnost društva od počinilaca kriminalnih dela, istovremeno ne mogu da obezbede sigurnost osuđenih koji se u njemu nalaze.

\section{Deprivacija sigurnosti i prethodna sankcionisanost}

U potrazi za onim činiocima koji bi mogli imati uticaja na javljanje i stepen prisustva deprivacije sigurnosti, uključen je u analizu i faktor prethodne krivične sankcionisanosti osuđenog lica. 
Jovanić, G.: (Ne)sigurnost u zatvoru

Tabela 15 - Deprivacija sigurnosti i prethodna sankcionisanost

\begin{tabular}{lcccccccc}
\hline & \multicolumn{7}{c}{ DEPRIVACIJA SIGURNOSTI } \\
\cline { 2 - 9 } $\begin{array}{l}\text { izricanje krivične } \\
\text { sankcije }\end{array}$ & $\begin{array}{c}\text { nizak nivo } \\
\text { deprviranosti }\end{array}$ & $\begin{array}{c}\text { povišen nivo } \\
\text { depriviranosti }\end{array}$ & $\begin{array}{c}\text { visok nivo } \\
\text { depriviranosti }\end{array}$ & \multicolumn{2}{c}{ ukupno } \\
\cline { 2 - 10 } & br & $\%$ & br & $\%$ & br & $\%$ & br & $\%$ \\
\hline primarno kažnjeni & 16 & 15,0 & 58 & 54,2 & 33 & 30,8 & 107 & 58,5 \\
\hline legalni recidivisti & 11 & 14,5 & 46 & 60,5 & 19 & 25,0 & 76 & 41,5 \\
\hline ukupno & 27 & 14,8 & 104 & 56,8 & 52 & 28,4 & 183 & 100,0 \\
\hline
\end{tabular}

Uvid u odgovore ispitanika u Tabeli 15 pokazuje, osim činjenice da se preko polovine odgovora ispitanika u obe kategorije koncentriše na povišenu depriviranost i to da nema velikih odstupanja u iskazivanju stepena depriviranosti u odnosu na primarno kažnjene i legalne recidiviste.

Odsustvo statistički značajnog korelativnog odnosa $(\mathrm{p}=0,464)$ daje materijala za tvrdnju da osuđena lica pogađa deprivacija sigurnosti bez obzira da li su bili na udaru krivičnih sankcija pre dolaska u penitersijernu ustanovu ili ne.

\section{Deprivacija sigurnosti i penalni recidivizam}

Penalni recidivizam kao faktor koji govori o većem stepenu društvene opasnosti osuđenog je varijabla koja je uzeta u razmatranje prilikom statističke obrade i analize podataka, u nameri sagledavanja kvaliteta međusobnog uticaja tih varijabli.

Tabela 16 - Deprivacija sigurnosti i penalni recidivizam

\begin{tabular}{lcccccccc}
\hline \multirow{2}{*}{$\begin{array}{l}\text { penalni } \\
\text { recidivizam }\end{array}$} & $\begin{array}{c}\text { nizak nivo } \\
\text { deprviranosti }\end{array}$ & \multicolumn{2}{c}{ povišen nivo } & \multicolumn{2}{c}{$\begin{array}{c}\text { visok nivo } \\
\text { depriviranosti }\end{array}$} & depriviranosti & \multicolumn{2}{c}{ ukupno } \\
\cline { 2 - 10 } & br & $\%$ & br & $\%$ & br & $\%$ & br & $\%$ \\
\hline prvi put zatvoren & 22 & 17,1 & 71 & 55,0 & 36 & 27,9 & 129 & 70,5 \\
\hline penalni recidivist & 5 & 9,3 & 33 & 61,1 & 16 & 29,6 & 54 & 29,5 \\
\hline ukupno & 27 & 14,8 & 104 & 56,8 & 52 & 28,4 & 183 & 100 \\
\hline
\end{tabular}

Podaci iz Tabele 16 ukazuju na činjenicu da se učešća odgovora penalnih recidivista i nerecidivista ne razlikuju u većoj meri. Obe grupe ispitanika najčešće se izjašnjavaju da deprivacija sigurnosti kod njih dostiže povišen nivo (55-60\%), nešto manje od trećine da su visoko deprivirani, a najmanje učešće odgovora saopštava odsustvo deprivacije sigurnosti (15\%). 
Odsustvo statistički značajne korelacije penalnog recidivizma i deprivacije $(\mathrm{p}=0,496)$ navodi na zaključak da deprivacija sigurnosti pogađa osuđena lica bez obzira da li se na izvršenju kazne zatvora nalaze prvi put ili su u prošlosti imali iskustva sa životom u zatvoru.

\section{Deprivacija sigurnosti i starost osuđenih}

Činjenice da se neka osoba nalazi u životnom dobu koje sobom nosi veću fizičku spremnost, a druga u antipodu laganog umanjenja sposobnosti i gubitka vitalnosti (i mogućnosti da se u situaciji pretnje odbrani), uzete su u analizi kao faktor koji bi mogao imati uticaja na intenzitet deprivacije sigurnosti.

Tabela 17 - Deprivacija sigurnosti i starost osudenih

\begin{tabular}{lcccccccc}
\hline & \multicolumn{7}{c}{ DEPRIVACIJA SIGURNOSTI } \\
\cline { 2 - 10 } $\begin{array}{l}\text { starosna } \\
\text { grupa }\end{array}$ & $\begin{array}{c}\text { nizak nivo } \\
\text { deprviranosti }\end{array}$ & \multicolumn{2}{c}{ povišen nivo } & \multicolumn{2}{c}{ visok nivo } & \multicolumn{2}{c}{ ukupno } \\
\cline { 2 - 10 } & depriviranosti & depriviranosti & br & $\%$ \\
\hline do 21 g. & 7 & 18,9 & 23 & 62,2 & 7 & 18,9 & 37 & 20,2 \\
\hline $22-30 \mathrm{~g}$ & 11 & 13,9 & 47 & 59,5 & 21 & 26,6 & 79 & 43,2 \\
\hline $31-45 \mathrm{~g}$ & 7 & 15,6 & 23 & 51,1 & 15 & 33,3 & 45 & 24,6 \\
\hline 46-60 g. & 2 & 11,1 & 10 & 55,6 & 6 & 33,3 & 18 & 9,8 \\
\hline preko 60 g. & - & - & 1 & 25,0 & 3 & 75,0 & 4 & 2,2 \\
\hline ukupno & 27 & 14,8 & 104 & 56,8 & 52 & 28,4 & 183 & 100 \\
\hline
\end{tabular}

Podaci izloženi u Tabeli 17 potvrđuju očekivanja jer se može videti da je prisutan linearan porast učešća odgovora koji označavaju visok nivo depriviranosti, uporedo sa porastom godina života, a s druge strane sa smanjenjem godina života više je osuđenih koji se osećaju sigurno u penalnim ustanovama.

Centralna kategorija, povišena depriviranost, ipak je najzastupljenija kod svih kategorija osuđenih, što govori da se osuđena lica ne osećaju baš bezbedno i sigurno u uslovima izvršenja kazne zatvora.

Postojanje statistički značajne korelacije $(\mathrm{r}=0,163 ; \mathrm{p}=0,028)$ pozitivnog predznaka, ukazuje na činjenicu da je potrebno preduzeti dodatne mere u cilju obezbeđenja veće sigurnosti starijih kategorija osuđenih lica (izdvajanjem $\mathrm{u}$ homogene grupe, raspoređivanjem $\mathrm{u}$ boravišne i radne uslove $\mathrm{u}$ kojima će biti manje izloženi napadima i ugrožavanjima od strane mlađih osuđenika). 


\section{Deprivacija sigurnosti i obrazovanje osuđenih}

Obrazovanje, kao mogući značajan faktor, dovođeno je takođe u vezu sa deprivacijom sigurnosti.

Tabela 18 - Deprivacija sigurnosti i obrazovanje osudenih

\begin{tabular}{lcccccccc}
\hline \multirow{2}{*}{ školska sprema } & \multicolumn{7}{c}{ DEPRIVACIJA SIGURNOSTI } \\
\cline { 2 - 11 } & $\begin{array}{c}\text { nizak nivo } \\
\text { deprviranosti }\end{array}$ & \multicolumn{2}{c}{ povišen nivo } & \multicolumn{2}{c}{ visok niviviranosti } & depriviranosti & \multicolumn{2}{c}{ ukupno } \\
\cline { 2 - 11 } & br & $\%$ & br & $\%$ & br & $\%$ & br & $\%$ \\
\hline nepotpuna osn. šk. & - & - & 5 & 71,4 & 2 & 28,6 & 7 & 3,8 \\
\hline završena osn. šk & 7 & 20,6 & 19 & 55,9 & 8 & 23,5 & 34 & 18,6 \\
\hline nepotpuna srednja šk. & 2 & 6,1 & 18 & 54,5 & 13 & 39,4 & 33 & 18,0 \\
\hline završena srednja šk & 14 & 18,7 & 44 & 58,7 & 17 & 22,7 & 75 & 41,0 \\
\hline završen zanat & 2 & 8,7 & 11 & 47,8 & 10 & 43,5 & 23 & 12,6 \\
\hline visoka šk. sprema & 2 & 18,2 & 7 & 63,6 & 2 & 18,2 & 11 & 6,0 \\
\hline ukupno & 27 & 14,8 & 104 & 56,8 & 52 & 28,4 & 183 & 100 \\
\hline
\end{tabular}

I u ovom slučaju centralna kategorija, tj. povišena depriviranost najčešće je iskazivana, bez obzira o kojoj se kategoriji osuđenih radi tj. bez obzira na njihovu školsku spremu. Evidentno je da se uvek više osuđenih izjašnjava (osim onih sa visokom školskom spremom) da je visoko deprivirano nedostatkom sigurnosti, nego da ne strahuje za svoju bezbednost, pogotovu osuđeni koji nemaju ni osnovnu školu.

Zbog takve distribuje frekvencije nije utvrđena ni statistički značajna korelacija obrazovanja i deprivacije sigurnosti $(p=0,825)$. U tom smislu može se zaključiti da deprivacija sigurnosti pogađa osuđena lica nezavisno od njihovog obrazovnog nivoa. Školovan ili neškolovan, čovek u zatvoru je nebezbedan.

\section{Deprivacija sigurnosti i bračno stanje osuđenih}

U potrazi za odgovorom da li deprivacija sigurnosti teže pogađa osuđena lica koja su na slobodi ostavila bračnog/vanbračnog partnera od osuđenih koji ne žive u nekoj od bračnih formi, ukrštane su te dve varijable, a odgovori osuđenih kategorisani prema činjenici postojanja / nepostojanja formi braka prikazani su u Tabeli 19. 
Specijalna edukacija i rehabilitacija (Beograd), Vol. 13, br. 2. 141-172, 2014.

Tabela 19 - Deprivacija sigurnosti i bračno stanje osuđenih

\begin{tabular}{lcccccccc}
\hline \multirow{2}{*}{ bračno stanje } & \multicolumn{7}{c}{ DEPRIVACIJA SIGURNOSTI } \\
\cline { 2 - 11 } & $\begin{array}{c}\text { nizak nivo } \\
\text { depirviranosti }\end{array}$ & \multicolumn{2}{c}{$\begin{array}{c}\text { povišen nivo } \\
\text { depriviranosti }\end{array}$} & $\begin{array}{c}\text { visok nivo } \\
\text { depriviranosti }\end{array}$ & \multicolumn{2}{c}{ ukupno } \\
\cline { 2 - 11 } & br & $\%$ & br & $\%$ & br & $\%$ & br & $\%$ \\
\hline oženjen & 7 & 18,9 & 19 & 51,4 & 11 & 29,7 & 37 & 20,2 \\
\hline vanbrač. zajednica & 3 & 10,7 & 19 & 67,9 & 6 & 21,4 & 28 & 15,3 \\
\hline neoženjen & 14 & 14,9 & 56 & 59,6 & 24 & 25,5 & 94 & 51,4 \\
\hline razveden & 3 & 15,8 & 9 & 47,4 & 7 & 36,8 & 19 & 10,4 \\
\hline udovac & - & - & 1 & 20,0 & 4 & 80,0 & 5 & 2,7 \\
\hline ukupno & 27 & 14,8 & 104 & 56,8 & 52 & 28,4 & 183 & 100,0 \\
\hline
\end{tabular}

Opšti uvid u odgovore osuđenih iz Tabele 19 govori da su udovci najugroženija kategorija što se tiče strahovanja za svoju bezbednost (4 od 5 ispitanika). Međutim, ako se vratimo na Tabelu 17, zapazićemo da su to upravo oni najstariji osuđenici, čije strahovanje za sopstvenu sigurnost više možemo pripisati njihovim godinama života (mada su se u ovom slučaju te dve činjenice koncentrisale kod istih osuđenika).

U kategoriji visoke depriviranosti najmanje učešće su iskazali osuđeni koji održavaju vanbračnu vezu. Najveće učešće u kategoriji odsustva deprivacije sigurnosti ostvarili su oženjeni, ali s obzirom na sličan model odgovaranja svih kategorija osuđenika, nije utvrđena statistički značajna korelacija varijabli bračnog statusa i deprivacije sigurnosti $(p=0,262)$.

\section{DISKUSIJA}

Cilj ovog rada je bio da ispitamo da li deprivacija sigurnosti postoji u našim zatvorima, u kojoj meri je prisutna i da li se stepen tog prisustva može dovesti u vezu sa različitostima u odnosu na tip zatvora, demografske, socijalno-psihološke ili kriminološko-penološke karakteristike osuđenih lica.

Uzorak ispitanika je anketiran opštim upitnikom (kojim su prikupljeni podaci o varijablama vezanim za osnovne demografske, kriminološkopenološke i socijalno-psihološke podatke) i Skalom za ispitivanje depriviranosti osuđenih lica deprivacijom sigurnosti (SIG), standardizovanom od strane Instituta za kriminološka i sociološka istraživanja u Beogradu (Radovanović, 1992), koja ima 34 pitanja i rađena je po principu Likertove skale. Dobijeni skorovi su kategorisani u tri grupe odgovora koji podrazumevaju tri nivoa: nizak, povišen i visok nivo depriviranosti. 
Sumirajući razmatranja o odnosu deprivacije sigurnosti i nezavisnih varijabli koje su dovođene u vezu sa navedenom zavisnom varijablom, može se konstatovati da deprivacija sigurnosti ostvaruje statistički značajan odnos sa starošću osuđenih $(\mathrm{r}=0,163 ; \mathrm{p}=0,028)$, tako što se porastom godina života povećava i bojazan za sopstvenu bezbednost unutar zatvora. Sa drugim ispitivanim nezavisnim varijablama, deprivacija sigurnosti nije u korelativnom odnosu.

Najveći broj ispitanika (između 50-60\%) se nalazi u kategoriji povišene depriviranosti. To s druge strane nameće pitanja poštovanja pravila o raspoređivanju osuđenih, kvalitetnoj kategorizaciji i separaciji, nadzora nad njihovim ponašanjem, kontrole neformalnog osuđeničkog kolektiva i sličnih problema, koji opterećuju izvršenje kazne zatvora.

Ukoliko se osuđeni ne oseća bezbedno u penalnoj ustanovi, otežano je dobijanje informacija o njihovim interpersonalnim odnosima unutar vaspitnih grupa, unutar neformalnog osuđeničkog kolektiva, o problemima koje on lično ima u ustanovi, pa se time otežava ili onemogućava istraživački poduhvat. Paradoks je, kako neki autori zapažaju (Ilić i Jovanić, 2011), da su zatvori kao ustanove koje su stvorene radi bezbednosti društva od kriminaliteta, nedovoljno bezbedni za građane koji se u njima nalaze.

\section{ZAKLJUČAK}

Istraživanjem je ustanovljeno da osuđeni u zatvoru strahuju za sopstvenu bezbednost. Ta konstatacija navodi na razmišljanje da li smo kao društvo učinili dovoljno da im osim kazne pružimo i nešto više. Većina će smatrati da jeste, osuđeni će smatrati da nije, a nama ostaje da uvek iznova preispitujemo postojeće stanje, prikazujući ga onakvim kakvim jeste, ukazujući na moguća poboljšanja u tom sistemu.

Ukazivanje na postojanje deprivacije sigurnosti u našim zatvorima ima značaja za praksu izvršenja kazne zatvora. Saznanja o kvalitetu i intenzitetu nesigurnosti osuđenih daju osnov za preduzimanje mera i aktivnosti usmerenih na redukciju te negativne posledice boravka u zatvoru. Takva aktivnost ne iziskuje uvek posebna materijalna izdvajanja već se može ostvariti preraspoređivanjem i reklasifikovanjem osuđenih unutar ustanova. $\mathrm{Na}$ taj način se ne bi mnogo izgubilo, a mogući dobri efekti tih napora bili bi obostrana korist i povećanje sigurnosti i za ustanovu i za osuđene. 
Rezultati istraživanja takođe ukazuju da nije dovoljno oslanjanje samo na činjenice koje prikazuje oficijelni sistem izvršenja, već je potrebno uvažavati i viđenje osuđenih. Oni su najosetljivija karika u lancu izvršenja, preko čijih interesa, prava, dostojanstva i životnih situacija se u krajnjoj liniji prelama svako smanjenje i povećanje dejstva deprivacija.

Velika je mudrost i veština pronaći pravu meru otežavanja i olakšavanja položaja osuđenih u penalnim uslovima, jer se u svakom slučaju izaziva reakcija neke interesne grupe, pa i društva u celini. Ekstremni kritičari bi zagovarali napuštanje koncepcije penalne rehabilitacije, povratak na retribuciju, odmazdu i izolaciju. S druge strane, kao antipodu bismo imali zagovornike ukidanja zatvora, kao nehumanog, neefikasnog i štetnog kako po osuđene, tako i po društvo. Svakako se ne bismo složili ni sa jednima ni sa drugima, već bismo na ovom mestu zagovarali racionalnija rešenja, koja bi sadržala dva centralna zahteva.

Prvi je da se realno procene dosadašnji napori u pravcu ostvarenja koncepta penalne rehabilitacije. Ta procena mora obuhvatiti teorijsko-konceptualni, normativni, materijalno-tehnički, kadrovski i programski nivo.

Drugi je zahtev da se sagledaju objektivne mogućnosti osnivanja ili reorganizacije postojećih ustanova za izvršenje kazne zatvora u pravcu stvaranja po suštini različitih, ali zaista različitih kazneno-popravnih zavoda. U njima bi se morao diferencirati tretman različitih kategorija osuđenih lica. Sadržinski različiti modeli tretmana osuđenih moraju biti prilagođeni riziku recidivizma i potrebama za tretmanom osuđenih lica. Sam tretman unutar ustanova morao bi odgovarati deklarativnoj nameni konkretnog zatvora.

Založili bismo se i za istovremenu analizu kadrova koji rade kao stručno osoblje tih ustanova, u smislu njihove brojnosti, proporcionalnosti ostalim službama u ustanovama, kvalifikovanosti, opterećenosti, sadržinske realizacije tretmana (Jovanić, 2010b). Uz sve pomenuto insistirali bismo i na konstantnoj evaluaciji toka i efekata penalne rehabilitacije. Tek tada bismo došli do mogućnosti da argumentovano tvrdimo da li postojeća koncepcija zaista doživljava krizu, da li se pokazuje kao uzaludan napor u represiji kriminaliteta ili se nije dovoljno učinilo ni da takva koncepcija zaživi, a kamoli da pokaže očekivane efekte i ostvari potencijale zbog kojih je i zagovarana. 


\section{LITERATURA}

1. Bucklen, K., Zajac, G. (2009). But Some of Them Don't Come Back (to Prison!): Resource Deprivation and Thinking Errors as Determinants of Parole Success and Failure The Prison Journal 89. Pristupljeno maj 2011. sa http://tpj.sagepub.com/ cgi/content/abstract/89/3/239

2. Graffam, J., Shinkfield A. J. (2009). Reintegration for Ex-Prisoners. Thousand Oaks, CA: Sage Publications. http://ijo.sagepub.com/ content $/ 54 / 3 / 346$

3. Green, C., Andre, G., Kendall, K., Looman, T., \& Polvi, N. (1992). A study of 133 suicides among Canadian federal prisoners. Forum on Corrections Research, 4. http://www.csc-scc.gc.ca/text/pblct/forum/ e043/043i_e.pdf

4. Ignjatović, Đ. (2006). Kaznena reakcija u XXI veku izazovi i dileme, Zbornik radova „Novo krivično zakonodavstvo dileme i problemi u teoriji i praksi”, Beograd: Institut za sociološka i kriminološka istraživanja.

5. Ilić, Z., Jovanić, G. (2009). Kriminalitet i zavodske sankcije. U: D. Radovanović, (ur.), Istraživanja u specijalnoj pedagogiji. (str. 243-256). Beograd: Univerzitet u Beogradu Fakultet za specijalnu edukaciju i rehabilitaciju.

6. Ilić, Z. i Jovanić, G. (2011). Zatvor i/ili sloboda pod nadzorom. Beograd: Univerzitet u Beogradu - Fakultet za specijalnu edukaciju i rehabilitaciju.

7. Jašović, Ž. (2000). Penološka andragogija. Beograd: Institut za kriminološka i sociološka istraživanja.

8. Jovanić, G. (2007a). Negativne posledice izvršenja kazne zatvora. Magistarska teza odbranjena na Univerzitet u Beogradu - Fakultet za specijalnu edukaciju i rehabilitaciju.

9. Jovanić, G. (2007b). Specifičnosti izvršenja kazne maloletničkog zatvora. U: D., Radovanović, (ur.), Poremećaji ponašanja i prestupništvo mladih: specijalno - pedagoški diskurs. (str. 397-414). Beograd: Univerzitet u Beogradu Fakultet za specijalnu edukaciju i rehabilitaciju - Centar za izdavačku delatnost.

10. Jovanić, G. (2010a). Krivično-pravni i penološki recidivizam osuđenih lica. Specijalna edukacija i rehabilitacija, 10(2), 271-281. 
11. Jovanić, G. (2010b). Potrebe za tretmanom i njegova realizacija u penitensijarnim uslovima. U: V. Žunić-Pavlović, M. Kovačević -Lepojević, (ur.), Prevencija i tretman poremećaja ponašanja. (str. 257276). Beograd: Univerzitet u Beogradu Fakultet za specijalnu edukaciju i rehabilitaciju.

12. Jovanić, G. (2011a). Izvršenje kazne zatvora i društvena kriza, U: Z. Isailović, (ur.), Zbornik radova međunarodne naučne konferencije „Pravni sistem i društvena kriza“, Sveska druga: (str. 477-494). Kosovska Mitrovica: Pravni fakultet u Prištini sa privremenim sedištem u Kosovskoj Mitrovici.

13. Jovanić, G. (2011b). Tranzicija zatvora u tranziciji društva, U: N. Glumbić, V. Vučinić, (ur.), Specijalna edukacija i rehabilitacija danas: (str. 483-488). Beograd: Univerzitet u Beogradu Fakultet za specijalnu edukaciju i rehabilitaciju.

14. Jovanić, G. (2013). Tretman osuđenih sa invaliditetom u zatvoru. U: V. Žunić-Pavlović, (ur.) Zbornik radova VII Međunarodnog skupa "Specijalna edukacija i rehabilitacija danas", 27-29. septembar 2013. (str. 159-168). Beograd: Fakultet za specijalnu edukaciju i rehabilitaciju.

15. Jovanić, G., Žunić, V., Ilić, Z. (1999). Kriminalitet maloletnika i krivičnopravna reakcija u Srbiji (1990-1995). Beogradska defektološka škola, 99(1), 101-121.

16. Lowenkamp, C. T., Latessa, E. J., \& Smith, P. (2006). Does correctional program quality really matter? The impact of adhering to the principles of effective intervention. Criminology \& Public Policy, 5, 575-594.

17. Marić, B., Radoman, M. (2001). Pobune u zatvorima Srbije. Beograd: Institut za kriminološka i sociološka istraživanja.

18. McDougall, C., Cohen, M.A., Swaray, R., \& Perry, A. (2003). The Costs and Benefits of Sentencing: A Systematic Review. Annals of the American Academy of Political and Social Science, 587, 160-177.

19. Palermo, G. B. (2009). Reintegration and Recidivism. Thousand Oaks, CA: Sage Publications. Pristupljeno februar 2011 sa: http://ijo.sagepub. com/content $/ 53 / 1 / 3$

20. Radovanović, D. (1992). Čovek i zatvor - studija integrisanosti u zatvornički društveni sistem. Beograd: Prometej i Institut za kriminološ$\mathrm{ka}$ i sociološka istraživanja. 
21. Santos, M. (1995). Facing long-term imprisonment. In Flanagan, T. J. (Ed.), Long-term imprisonment: Policy, science and correctional practice (pg. 36-40) London: Sage Publications.

22. Sykes, G. (1958). The Society of Captives: a Study of a Maximum Security Prison. New Jersey: Princeton University Press

23. Špadijer-Džinić, J. (1973). Zatvoreničko društvo. Beograd: Institut za kriminološka istraživanja.

24. Visher, C., Travis, J. (2003). Transitions from prison to community: Understanding individual pathways. Annual Review of Sociology, 29, 89-113. 


\title{
(IN)SECURITY IN PRISON
}

\author{
Goran Jovanić \\ University of Belgrade - Faculty of Special Education and Rehabilitation
}

\begin{abstract}
Summary
The main aim of this research was to determine the level of security deprivation in convicted persons in different types of correctional institutions, and to determine the relation between deprivation and demographic, socio-psychological, criminal and penal characteristics. Another goal of this research was to obtain scientific information about the quality and intensity of security deprivation, as one of the consequences of imprisonment and perception differences of different categories of convicted persons. The sample consisted of 183 male convicts serving their sentence in Correctional institution for juvenile delinquents and young adults in Valjevo, Correctional institution Padinska Skela, Correctional Institution Požarevac, and County prison in Pančevo. The examinees were questioned by means of a general questionnaire for collecting data on the variables related to basic criminal, penal, and socio-psychological information, and by the Scale for testing security deprivation - SIG (Radovanović, 1992), consisting of 34 questions following the principle of the Likert scale (Cronbach's $\alpha=0,952$ ). Research results indicate that about $15 \%$ of the examinees express low level of deprivation, about 56\% increased level, and about $28 \%$ high level of deprivation. Security deprivation is significantly related to age $(r=0,163 ; p=0,028)$, in a way that the level of deprivation increases with age. There is no correlation with other tested independent variables. Such situation raises questions about respecting the rules related to categorization of prisons, placing convicts in prisons, special protection of old people in prison, separating aggressive and dangerous convicts, monitoring their behavior, controlling informal groups of convicts, and similar problems related to imprisonment.
\end{abstract}

Key words: sentence, prison, convicts, security, deprivation

Primljeno: 21.5.2014.

Prihvaćeno: 15.10.2014. 